УДК 37.013.42:37.018.1

DOI:

Алла Ревть, кандидат педагогічних наук, дочент кафедри соичільної педагогіки та корекиійної освіти Дрогобицького державного педагогічного університету імені Івана Франка

Ігор Гриник, кандидат педагогічних наук, доцент кафедри сочіальної педагогіки та корекиійної освіти Дрогобицького державного педагогічного університету імені Івана Франка

\title{
ОСОБЛИВОСТІ СОЦІАЛЬНО-ПЕДАГОГІЧНОЇ РОБОТИ 3 ПРОФІЛАКТИКИ НАСИЛЬСТВА ЩОДО ДІТЕЙ
}

У статті йдеться про проблему насильства над дітьми та важливість попередження жорстокого ставлення до дітей. Охарактеризовані зміст, форми та методи соиіально-педагогічної роботи з профілактики насильства щодо дітей, окреслено особливості діяльності соціального педагога загальноосвітньої школи у вирішенні даної проблеми. Обтрунтовано важливість профілактики на первинному, вторинному та третинного рівнях, пріоритетність родинного виховання і сімейних духовних иінностей у вихованні та формуванні особистості дитини.

Ключові слова: насильство; профілактика; соціально-педагогічна робота; дитина.

Jim. 6.

Alla Revt, Ph.D.(Pedagogy), Associate Professor of the Social Pedagogy and Correctional Education Department

Drohobych Ivan Franko State Pedagogical University

Ihor Hrynyk, Ph.D.(Pedagogy), Associate Professor of the Social Pedagogy and Correctional Education Department Drohobych Ivan Franko State Pedagogical University

\section{FEATURES OF SOCIO-PEDAGOGICAL WORK ON THE PREVENTION OFVIOLENCE AGAINST CHILDREN}

The article deals with the problem of violence against children and the importance of preventing the abuse of children. The content, forms and methods of socio-pedagogical work on the prevention of violence against children are analysed, the main aspects of the social pedagogue's work at a secondary school in the solution of this problem are outlined.

The development of adequate strategies of social and pedagogical work with the family, aimed at forming a sense of respect for the child's personality, which at the present stage of civilization plays a special role, is characterized.

The purpose of the article is to outline the features of social pedagogical work on the prevention of violence against children.

The socio-pedagogical work on the prevention of violence against children is defined as a kind of social and pedagogical activity carried out by a number of authorized structures aimed at preventing, eliminating and overcoming factors of the risk of violence against children; early detection of violence; organization of a system of measures aimed at providing assistance to a child who has suffered from violence, as well as work with an aggressor in order to prevent repeated cases of violence.

It is determined that a social educator must work with each child, using the school's capabilities to prevent possible child-related asocial activities.

The importance of prevention at the primary, secondary and tertiary levels, as well as the priority of family education and family spiritual values in the education and formation of the child's personality is substantiated.

It has been established that the key to successful child abuse prevention efforts will be to increase the qualifications of specialists working in the field of child protection, prevention of violence and rehabilitation.

Keywords: violence; prevention; social and pedagogical work; a child.

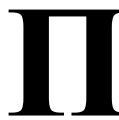
остановка проблеми. Насильство стало дуже серйозною проблемою людства яке набирає масштабних обертів. Ця проблема не знає ні державних кордонів, ні соціального розшарування у суспільстві. Насильство може торкнутися як людей з вищою освітою, так і людей, які ніколи не навчалися, як бідних, так і багатих. І ніхто не може дати відповіді на запитання та пророкувати, коли й де насильство може відбутися.

Проблема насильства та жорстокого поводження щодо дітей та інших категорій 


\section{ОСОБЛИВОСТІ СОЦІАЛЬНО-ПЕДАГОГІЧНОЇ РОБОТИ ЗПРОФІЛАКТИКИ НАСИЛЬСТВАЩОДО ДІТЕЙ}

населення в Україні залишається нерозв'язаною, а тому стає дедалі актуальнішою, особливо на тлі зростання показників цього явища, яке набуває епідемічного характеру. Одна з гострих проблем, які постають перед сучасним українським суспільством це прояв насильства в сім'ї.

Проблема насильства щодо дітей досліджується багатьма вченими, зокрема: теоретичні засади проблеми насильства над дітьми розглядають I. Звєрєва, Н. Максимова, К. Мілютіна; природу та наслідки насильства розкривають Т. Сафоновата, Е. Цимбал. Пошук соціально-педагогічних умов, причин і факторів виникнення, виявлення та подолання насильства над дітьми досліджують такі вчені, як Т. Гончарова, О. Коломієць, О. Кочемировська та ін.

Правові, соціальні, психологічні та медичні аспекти запобігання насильства представлені в роботах В. Бондаровської, О. Кочемировської, Г. Лактіонової, В. Міленко, Ю. Онишко, Р. Хаар, Г. Христова та ін.

Мета статті - окреслити особливості соціально-педагогічної роботи з профілактики насильства щодо дітей.

Виклад основного матеріалу дослідження 3 повним обгрунтуванням отриманих наукових результатів. У Законі України "Про соціальну роботу з сім'ями, дітьми та молоддю” чітко дано визначення поняття соціальної роботи з дітьми та молоддю, де вказано, що це діяльність уповноважених органів, підприємств, організацій та установ незалежно від їх підпорядкування форми власності, та окремих громадян, яка спрямована на створення соціальних умов життєдіяльності, гармонійного та різнобічного розвиткудітей та молоді, захист їх конституційних прав, свобод і законних інтересів, задоволення культурних та духовних потреб $[2,33]$.

Соціально-педагогічна робота з профілактики насильства щодо дітей - це різновид соціальнопедагогічної діяльності, що здійснюється рядом уповноважених структур, спрямований на попередження, усунення та подолання чинників ризику виникнення насильства щодо дітей; раннє виявлення насильства; організацію системи заходів, спрямованих на надання допомоги дитині, яка постраждала від насильства, а також на роботу з агресором з метою недопущення повторних випадків насильства [1].

Соціальна профілактика розглядається як усвідомлена та спеціально організована діяльність, яка має такі основні стадії та таку основну послідовність:

- Першою стадією є профілактика. Важливість іiі полягає в тому, що у людини формують певну систему із допустимих цінностей, які притаманні суспільству. Надалі, це дозволяе їй уникати неприйнятних форм поведінки та конкретної діяльності, що несуть в собі загрозу для самої людини та її навколишнього оточення. Дитину слід виховувати згідно гуманістичного підходу, що створює для неї підгрунтя для великого кола знайомств, вміння будувати взаємини із людьми, вільно спілкуватись, та легко взаємодіяти із ними.

- Друга стадія - це запобігання. Вона спрямовується на заходах, які перешкоджають виникненню ситуацій, які б могли нести в собі загрозу для життєдіяльності самої особи, а також найближчого для неї оточення. На цій стадії потрібно інформувати людей щодо протиправних дій, а також про те, які наслідки вони в собі можугь містити. Саме за допомогою такого способу ми запобігаємо виникненню актів насильства $[6,72]$.

- Третя стадія - присікання. Це система у будь-якому суспільстві, яка спрямовується на блокування протиправної поведінки, яка може нести в собі згубні наслідки для самої особи, а також загрозу для навколишніх чи близьких. Для цього використовуються різноманітні, адміністративні, законодавчі, моральні та педагогічні санкції, якими керуються для покарання за скоєння певних дій чи злочинів та не допускають їхнього рецидиву $[6,72]$.

Робота соціального педагога в загальноосвітніх закладах 3 профілактики насильства має проводитись на таких трьох рівнях, а саме:

- Первинна профілактика має бути спрямована на загальну просвіту всіх суб'єктів навчальновиховного процесу. Проводиться інформування щодо жорстокого поводження 3 дітьми, насильства до дітей, та захисту прав дітей. Така робота проводиться соціальним педагогом із педагогічними працівниками, медичним та технічним персоналом навчального закладу, самими учнями та їхніми батьками;

- Вторинна профілактика проводиться соціальним педагогом із дітьми, їхніми сім'ями, які перебувають у складних життєвих обставинах. Така робота спрямована на покращення сімейних відносин, формування позитивного ставлення батьків до дитини, підтримка таких сімей, формування у батьків любові до дітей та гуманного ставлення до них, ознайомлення батьків із відповідальністю за вчинення насильства щодо дитини;

- Робота соціального педагога на третинному рівні профілактики проводиться із жертвами насилля, вона спрямована на навчання дитини самозахисту $[4,33]$. 


\section{ОСОБЛИВОСТІ СОЦІАЛЬНО-ПЕДАГОПІЧНОЇ РОБОТИ ЗПРОФІЛАКТИКИ НАСИЛЬСТВАЩОДО ДІТЕЙ}

До основних завдань первинної профілактики насильства щодо дітей відносять:

1. Підвищення в батьків компетенції; підвищення компетенції щодо раннього розвитку дитини; запровадження програм для підготовки молоді до сімейного життя; комплексні програми для молодого подружжя й тих хто збирається вступити в шлюб; формування усвідомленого батьківства;

2. Розробка профілактичних програм для позакласних годин із запобігання насильства;

3. Введення просвітницьких та освітніх програм для уникнення насильницької поведінки між чоловіками та жінками, а також дітьми та дорослими. Відмова від звичаїв та традицій виховання, які побудовані на диктатурі, фізичних покараннях, нетолерантності;

4. Повна ліквідація зон підвищеної небезпеки, таких як: погано освітлені вулиці; покинуті та зруйновані приміщення без охорони на них; підвищення патрулювання вулиць, в тому числі погано освітлених; розміщення зупинок громадського транспорту в безпечних місцях;

5. Підвищення кваліфікацій для фахівців, що працюють в сфері захисту дітей та профілактики насильства, а також тими хто проводять реабілітацію насильства та особами, що вчинили його. До таких фахівців належать соціальні педагоги, соціальні працівники, поліцейські, судді, лікарі, практичні психологи, вчителі, працівники в службах справ дітей, працівники прокуратури тощо.

6. Збільшення числа організації та проведення акцій на державному та місцевому рівнях, які спрямовані на профілактику насильства, формування чуйності, толерантності та гуманізму. Сюди відносять зокрема акції “16 днів без насильства".

Виділяють такі основні завдання вторинної профілактики насильства щодо дітей:

1. Раннє втручання в сім'ї де відбувається насильство щодо дитини, або уникнення його виникнення в неблагополучній сім' $і$;

2. Допомога в подоланні та виявленні чинників, що провокують насильство над дитиною;

3. Патронаж сім'ї, підтримка та соціальний супровід, коли іiі члени перебувають у складних життєвих обставинах;

4. Обов'язкове підвищення кваліфікації для вихователів, педагогів, та інших фахівців, які працюють в таких установах, як притулках для дітей, інтернатних закладах, спеціалізованих інтернатних закладах, виховних колоніях, центрах соціальнопсихологічної реабілітації дітей, приймальникахрозподільниках для дітей тощо, 3 метою ознайомлення з новими методами виховання [1].
До основних завдань третинної профілактики насильства щодо дітей відносять:

1. Негайне кризове втручання та обов'язкове вилучення дитини із середовища де відбувається чи відбулось насильство;

2. Неодмінне та безоплатне надання дитині комплексної допомоги, що стала жертвою насильства;

3. Розробка та функціонування на державному рівні програм, для успішної реабілітації дітей, що стали жертвами насильства.

4. Розробка та функціонування на державному рівні програм, для несення відповідальності та покарання особами, що вчинили насильство, в тому числі й над дітьми, враховуючи їхню стать, вік так інші особистісні характеристики [1].

У своїй діяльності соціальний педагог повинен використовувати такі форми просвітницької роботи щодо запобігання насильству:

- проведення лекційних заходів;

- організовувати фестивалі, акції та конкурси щодо запобігання насильству, формування негативного ставлення до його проявів тощо;

- ознайомлення учнів зі своїми правами;

- лекції у формі фільмів чи відеороликів щодо профілактики насильства;

- ознайомлення учнів із функціонуванням консультативних пунктів, куди вони зможуть звернутись у разі виникнення насильства щодо них, рідних, знайомих, та яку допомогу вони зможуть там отримати [3, 15].

Робота соціального педагога щодо насилля над дітьми спрямована на те, щоб запобігати цьому явищу. Тому соціальний педагог виконує такі завдання: інформує про сутність та наслідки насильства над дітьми, надає інформацію про відповідальність за вчинення цього злочину; вчить батьків використовувати моделі сімейного та суспільного виховання згідно гуманних принципів та дотримання демократії; роз'яснює права кожного із членів сім'і, вчить як їх відстоювати та як себе при потребі захистити; допомагає зміни ставлення суспільства щодо жорстоких форм виховання, звичаїв та традицій; активізує в людей громадську позицію; сприяє самореалізації дорослих та дітей [5, 217].

\section{ЛІТЕРАТУРА}

1. Журавель Т.В. Соціальна профілактика як напрямсоціально-педагогічноїдіяльності/Т.В.Журавель // Соціальна педагогіка : навч. посібник / За заг. ред. О. В. Безпалько; Авт.-кол. О. В. Безпалько, І.Д. Звєрєва, Т.Г. Веретенко та ін.: - К.: Академвидав, 2013. - С. 85-101. 
2. Закон України Про соціальну роботу з сім'ями, дітьми та молоддю від 21.06.2001 № 2558-III.

3. Капська А.Й. Соціальна педагогіка: підручник для студ. вищ. навч. закладів / М-во освіти і науки України, НПУ ім. М.П. Драгоманова; За ред. А.Й. Капська. - 2-ге вид., перероб. та доп. - Київ: Центр навчальної літератури, 2003. $256 \mathrm{c}$.

4. Лісова М.С. Попередження та протидія насильству в сім'ї / М.С. Лісова, М.П. Савченко. - Київ: Департамент освіти і науки виконавчого органу Київської міської ради (Київської міської державної адміністрації), 2015. - 92 с.

5. Система захисту дітей від жорстокого поводження: Навчально-методичний посібник / За ред.: К.Б. Левченко, І.М. Трубавіної. - К.: Держсоцслужба, 2005. - 124 с.

6. Социальная работа: теория и практика: Учебное пособие / Отв. ред. д.и.н., проф. Е.И. Холостова и др. - М.: ИНФА-М, 2004. - 427 с. (Высшее образование).

\section{REFERENCES}

1. Zhuravel, T.V. (2013). Socialna profilaktyka yak napryam socialno-pedagogichnoyi diyalnosti [Social prevention as a direction of social and pedagogical activity]. Social Pedagogy: teaching manual. Kyiv: Akademvydav, pp. 85-101. [in Ukrainian].
2. Zakon Ukrayiny Pro socialnu robotu z simyamy, ditmy ta moloddyu vid 21.06.2001 № 2558-III. [Law of Ukraine on Social Work with Families, Children and Youth 21.06.2001 No. 2558-III]. [in Ukrainian].

3. Kapska, A. J. (2003).Socialna pedagogika: pidruchnyk dlya stud. vyshh. navch. zakladiv [Social pedagogy: a textbook for students of higher educational institutions]. Ministry of Education and Science of Ukraine, National Mukhaylo Drahomanov Academy of Sciences of Ukraine.; (Ed.) A. Y. Kapska. The 2nd edition, modified and supplemented. Kyiv: Centr navchalnoyi literatury, 256 p. [in Ukrainian].

4. Lisova, M. S. (2015). Poperedzhennya ta protydiya nasylstvu $v$ simyi [Prevention and counteraction to domestic violence]. Kyiv: Departament osvity i nauky vykonavchogo organu Kyivskoyi miskoyi rady (Kyivskoyi miskoyi derzhavnoyi administraciyi), 92 p. [in Ukrainian].

5. Levchenko, K. B. \& Trubavinoyi, I. M. (Eds.). (2005). Systema zakhystu ditey vid zhorstokogo povodzhennya: Navchalno-metodychnyi posibnyk [System of protection of children from ill-treatment: Educational and methodical manual]. Kyiv: Derzhsoczsluzhba, 124 p.[in Ukrainian].

6. Socyalnaya rabota: teoriya i praktika: Uchebnoe posobie [Social work: theory and practice: textbook]. (Ed.). E.Y. Kholostova et al., Moscov: INFA-M, 427 p. [in Russian].

Стаття надійшла до редакції 10.12.2018

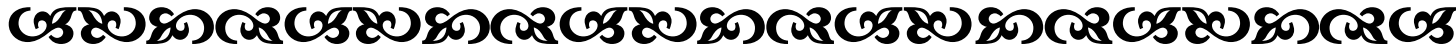

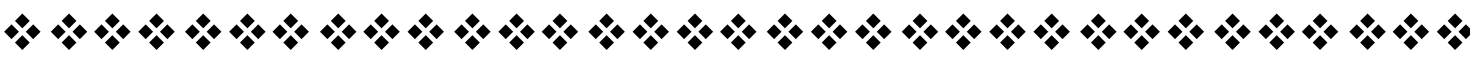

“Сім'я-иеджерело, водами яқого живиться річқа нашоїдержави. На моральному здоров'

гудові діти виростають у тих сім'ях, де батько $i$ мати по-справжньому люблять один одного $і$ водночас люблять і поважають людей”.

Василь Сухомлинський педагог, публічист, письменник

“Ви праві. Ми втомлюємося, від того, що треба підніматися до їхніх почуттів. Лідніматися, ставати навшпиньки, тягнутися. Ж्боб не образити".

Януши Корчак польський педагог, письменник, публіиист

“Фитина потребує вашої любові найбільше саме тоді, қоли вона найменше на неї заслуговує".

Ерма Бомбек американська письменниия

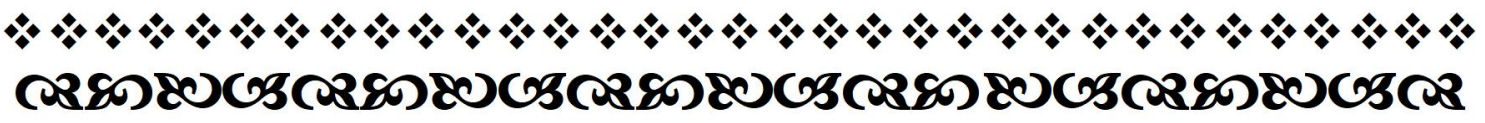

Молодь і ринок №1 (168), 2019 